\section{SCIENTIFIC ARTICLE}

Submitted: 23.07.2021

Revised: 10.09 .2021

Accepted: 30.09.2021

\author{
A.Yu. Moiseeva \\ Institute of Philosophy and Law, \\ Siberian Branch of the Russian Academy of \\ Sciences, Novosibirsk, Russian Federation \\ E-mail: abyssian03@gmail.com \\ ORCID: http://orcid.org/0000-0003-1440-9598
}

\title{
D. Chalmers and J. Perry on zombie problem and the content of phenomenal concepts
}

\begin{abstract}
David Chalmers and John Perry both construe phenomenal concepts as irreducible to descriptive concepts of physical properties or properties, which logically supervene on them. But they draw different conclusions from this point. D. Chalmers in "The Conscious Mind" argues that the epistemic gap between phenomenal and physical properties shows that the former cannot be ontologically identified with the latter. J. Perry in "Knowledge, Possibility and Consciousness" claims that we can identify phenomenal properties with physical ones without being committed to reductionism. In this paper I am going to examine Chalmers' and Perry's views on meaning and necessity, especially with respect to identity statements, in order to find where exactly their ways of thinking about the content of phenomenal concepts.

Key words: phenomenal properties; zombie world; two-dimensional semantics; levels of content; supervenience; identity; reduction.

Citation: Moiseeva, A.Yu. (2021), D. Chalmers and J. Perry on zombie problem and the content of phenomenal concepts, Semioticheskie issledovanija. Semiotic studies, vol. 1, no. 3, pp. 20-23, DOI: http://doi.org/10.18287/2782-2966-2021-1-3-20-23.

Information about conflict of interests: the author declares no conflict of interests.

(C) Moiseeva A.Yu., 2021 - Cand. Sc. Philosophy, Research Scholar, Institute of Philosophy and Law, Siberian Branch of the Russian Academy of Sciences, 8, Nikolaeva Street, Novosibirsk, 630090, Russian Federation.

\section{НАУЧНАЯ СТАТЬЯ \\ УДК 165}

\author{
А.Ю. Моисеева \\ Институт философии и права СО РАН, \\ г. Новосибирск, Российская Федерация \\ E-mail: abyssian03@gmail.com
}

ORCID: http://orcid.org/0000-0003-1440-9598
\end{abstract}

\section{Д. Чалмерс и Дж. Перри о проблеме зомби и содержании феноменальных понятий}

\footnotetext{
Аннотация: Дэвид Чалмерс и Джон Перри оба истолковывают феноменальные понятия как несводимые к дескриптивным понятиям физических свойств или свойств, которые логически супервентны на них. Но философы делают из этого разные выводы. Д. Чалмерс в «Сознающем уме» утверждает, что эпистемический разрыв между феноменальными и физическими свойствами показывает, что первые не могут быть онтологически отождествлены со вторыми. Дж. Перри же в «Знании, возможности и сознании» утверждает, что мы можем отождествлять феноменальные свойства с физическими, не будучи приверженными редукционизму. В настоящей статье я собираюсь исследовать взгляды Чалмерса и Перри на значение и необходимость, особенно в отношении утверждений тождества, чтобы найти, в чем именно расходятся их способы представления содержания феноменальных понятий.

Ключевые слова: феноменальное свойство; зомби-мир; двумерная семантика; супервентность; тождество; редукция.

Цитирование: Моисеева А.Ю. Д. Чалмерс и Дж. Перри о проблеме зомби и содержании феноменальных понятий // Семиотические исследования. Semiotic studies. 2021. T. 1, № 3. C. 20-23. DOI: http://doi.org/10.18287/2782-2966-2021-1-3-20-23.

Информация о конфликте интересов: автор заявляет об отсутствии конфликта интересов.

(c) Моисеева А.Ю., 2021 - кандидат философских наук, научный сотрудник, Институт философии и права СО РАН, 630090, Российская Федерация, г. Новосибирск, ул. Николаева, 8.
} 
It's no exaggeration to say that "The Conscious Mind" (Chalmers 1996) is one of the most important and disputed books on the philosophy of mind. In this book its author, David Chalmers, presents some arguments in favor of his position on the issue of the nature of qualitative mental states or, using good old philosophical terminology, phenomena. At first, he argues that our pheno menal concepts are irreducible to descriptive concepts of any physical properties or properties, which supervene on them. The main argument here is so called knowledge argument, but I will not focus on it now. Secondly, he moves from epistemology to ontology and argues that phenomenal properties cannot be identified with physical ones. Here he uses another, modal argument better known as an argument from zombies.

In philosophy of mind the word "zombie" does not mean the dead, which walks staggering, attacks people so as to eat them and has no ability to make meaningful conversation. Philosophical zombies are beings indistinguishable from people (or just from ourselves, to strengthen the argument) from the third-person perspective, but having no phenomenal experience. We can conceive a whole world physically identical with the actual one, but it is full of such zombies instead of conscious beings, and such world is metaphysically possible, as Chalmers claims. Strictly speaking, we cannot even be sure that our own world is not such a zombie world, although Chalmers himself prefers not to go that far. One way or another, but the argument from zombies, if it is correct, proves physicalism to be false. This argument is given in details in (Chalmers 1996, pp. 94-99, 131-134).

It should be noted right away that Chalmers' understanding of possibility is based on his view on meaning and content. To formalize the relevant aspect of the meaning of an expression he uses two-dimensional semantics. In his version of this theory every meaningful expression is associated with two functions. The first one, the so-called primary intension, is a function from possible worlds to extension of the expression, which reflects the way that actual-world reference is fixed. For example, the primary intension of the term "water" picks out the dominant clear, drinkable liquid in the oceans and lakes or, briefly, the watery stuff. Another function, the secondary intension, is a function from possible worlds to extension, fixing in each world the same referent, which is fixed by primary intension in actual world. Since it happens that the watery stuff in actual world is $\mathrm{H}_{2} \mathrm{O}$, the secondary intension of the term "water" is $\mathrm{H}_{2} \mathrm{O}$. If we imagine that we live in the world where the watery stuff is XYZ, then we should associate the term "water" with another secondary intension, namely XYZ. There are, so to speak, two levels of content, one of which is determined by actual world and the other - by counterfactual world or again the actual world, if it considered as a world of valuation. In the following table (Tab. 1), which is taken from Chalmers' review article (Chalmers 2006, p. 578), the left column represents worlds considered as actual and the top row represents worlds considered as worlds of valuation. The primary intention here is represented by diagonal, where the same world is considered as actual and as a world of valuation. The secondary intention is represented by rows.

Tab. 1

\begin{tabular}{|c|c|c|c|}
\hline & $\mathrm{H}_{2} \mathrm{O}$-world & XYZ-world & $\ldots$ \\
\hline $\mathrm{H}_{2} \mathrm{O}$-world & $\mathrm{H}_{2} \mathrm{O}$ & $\mathrm{H}_{2} \mathrm{O}$ & $\ldots$ \\
\hline $\mathrm{XYZ}$-world & $\mathrm{XYZ}$ & $\mathrm{XYZ}$ & $\ldots$ \\
\hline$\ldots$ & $\ldots$ & $\ldots$ & $\ldots$ \\
\hline
\end{tabular}

In accordance with his primary / secondary intention distinction, Chalmers distinguishes two kinds of propositions: primary and secondary ones. A statement is epistemically (or a priori) necessary, if and only if it associates with the necessary primary proposition; and a statement is metaphysically (or a posteriori) necessary, if and only if it associates with the necessary secondary proposition (Chalmers 2006, pp. 602-603). In the case of water recognition, the fact that watery stuff in actual world is $\mathrm{H}_{2} \mathrm{O}$ has led us to redefine the term "water" so that henceforth we began to consider that if there is a watery stuff not being $\mathrm{H}_{2} \mathrm{O}$ in counterfactual worlds, then it is not water, although we could take it for water looking with the naked eye. But in the case of phenomenal properties, as Chalmers claims, we cannot undertake such redefinition because the secondary intention here must be the same as primary intention. For example, it cannot be that some state seems to be the state of pain but is not the state of pain. By every plausible definition pain is what is sensed as pain, and nothing else. So, according to him, in this case there is no necessity at all.

In relation to the possibility of zombies this means that zombies are both epistemically and metaphysically possible. It is implausible, according to Chalmers, that zombies really exist anywhere, but it does not change matters. If there is no necessary connection between physical and phenomenal properties, then phenomenal properties, firstly, can't be reduced to physical properties or properties, which logically supervene on them, and, secondly, they are not physical properties and do not logically supervene on physical properties. Therefore, physicalism is false. We should presuppose at best natural supervenience, and it is this presupposition that underlies Chalmers' naturalistic dualism.

Indeed, it is often claimed that denial of logical supervenience of phenomena leads one to accept some kind of dualism. But, as we know, there are many philosophers who still search a way to confine themselves to the former and don't do the latter. John Perry, the author of "Knowledge, Possibility and Consciousness" (Perry 2001), is one of them. In denominated book he adopts the view that we can identify phenomenal properties with physical ones without be- 
ing committed to reductionism. In other words, Perry claims that it is coherent to deny both the possibility of zombie world and our ability to prove that it is impossible. His main idea is this: identity, contrary to common opinion, is the weaker relation than logical supervenience, so physicalist should not retreat to causal supervenience but should stick instead with identity. He stresses that physicalism can be construed as empirical hypothesis, not as a priori proved claim. This hypothetical version of physicalism, which Perry calls antecedent physicalism, has a significant advantage: its advocate should only prove that his theory is not a priori false. It is that Perry, as he claims, can do. Let's follow his argumentation.

Firstly, Perry, like Chalmers, accepts the premise that reducibility requires logical supervenience, i.e. the ability to formulate a priori some sufficient conditions of phenomenal properties in physical terms. He, again like Chalmers, argues the claim that we have no such ability, but with the help of another analysis. As Perry says, linguistic (and cognitive) content is not more than a way of classifying linguistic (and cognitive) events by their truth conditions. There are many ways of classifying, depending on what kind of information we consider as given and what kind of information we consider as additional. In general, he exposes this dependence in the following formula, which he calls "Content Analyzer":

CA: Given such and such, $\varphi$ is true if so and so,

where $\varphi$ is any truth-evaluable representation, such and such are facts about this representation, and so and $s o$ is the content assigned to $\varphi$ given those facts (Perry 2001, p. 125).

Consider, for example, the statement "Water is $\mathrm{H}_{2} \mathrm{O}$ ". If the condition that in English "water" means the watery stuff is given, then this statement is true if and only if the watery stuff is $\mathrm{H}_{2} \mathrm{O}$. In our world it is the case, but there are possible worlds where it is not the case. Perry calls such content, obtained by using only relevant rules of fixing reference, an attributive content. On the other side, if the condition that in English "water" refers to $\mathrm{H}_{2} \mathrm{O}$ is given, then this statement is true if and only if $\mathrm{H}_{2} \mathrm{O}$ is $\mathrm{H}_{2} \mathrm{O}$. Obviously, this is the case in every possible world. Perry calls such content, obtained by using rigidly fixed reference, a referential content. Attributive content and referential content, according to him, are two constituents of what he calls a subject matter content.

So far, we don't detect any significant advantages over the previous analysis. Perry's attributive and referential content is very similar to Chalmers' primary and secondary proposition respectively. But consider now the statement "This is $\mathrm{H}_{2} \mathrm{O}$ ", which is made by agent pointing at a stuff in a glass. This statement allows us to assign another type of content, namely context-dependent content. The content, given that in English "this" means, roughly, the object, which the speaker is pointing at, consist in that the object, which the speaker is pointing at, is $\mathrm{H}_{2} \mathrm{O}$. Such context-dependent content Perry calls reflexive content. It should be said that reflexivity in general is the cornerstone of Perry's semantics (See for example: Perry 1993); and it is reflexivity that he appeals to explaining irreducibility of phenomenal properties (Perry 2001, p. 145 and so forth). As he claims, our ability to conceive this or that counterfactual situation is based not on its possibility but on how we learn to use the terms in which this situation is described. The usual way to learn it is reflexive, and, therefore, reflexivity should be taken into account when analyzing the meanings of these terms.

The technical trick here is that Perry postulates the existence of special kind of signifiers, so-called inner demonstratives. Inner demonstratives are internal tokens functioning wholly like ordinary demonstratives "this" and "that", except the fact that they demonstrate not only things but also phenomenal properties, and because of them we can refer to phenomenal property, which is in fact physical property, without being able to formulate $a$ priori sufficient physical conditions of it. For example, I can think "This is pain", where "thi$s_{i}$ " is an inner demonstrative referring to phenomenal property of my actual state. If I'm not adhere, say, to the theory that pain is the property of stimulating C-fibers, then I would not be able to infer from my thought that my actual state is the state of having stimulated C-fibers, although it really is. More than that, I would be able to think about the same phenomenal property "This is the property of relaxing C-fibers" without incoherence. It is not because the identity of pain and stimulating C-fibers is not necessary. It is because my concept of pain and my concept of stimulating C-fibers would be received and supplemented from different sources and applied to different situations. As Perry himself expresses it, the information flow between them is blocked (Perry 2001, pp. 184-185). In relation to the possibility of zombies this means that zombies are epistemically possible but metaphysically impossible. The second claim here is postulated rather than proven. Perry simply presupposes all the referents of phenomenal concepts being fixed, and, since those referents are some physical properties, according to his antecedent physicalism, he gets a posteriori necessity.

Here it will be better to stop for a moment and grasp the state of affairs. Chalmers draws a conclusion about inconsistency of physicalism as ontological theory from epistemological considerations. Perry agrees with these considerations but not with Chalmers' conclusion. He seems to argue that epistemological considerations have no influence to the consistency of, at least, antecedent physicalism. The point, according to Perry, is that the identity of concepts of properties does not depend on the identity of properties themselves, no matter a priori or a posteriori. It does depend on relations between these concepts and other concepts, the most important of which are inner demonstratives referring to some previous experiences, namely the ex- 
periences serving as sources and applicandum of given concepts. These experiences determine the reference of concepts (Perry 2001, p. 185). Besides our concepts of phenomenal properties include some descriptions, which are believed to be satisfied by these properties. No matter are these descriptions formulated in physical terms or phenomenal terms or both, because, according to Perry, phenomenal terms refer to physical properties. If everything goes well, then these experiences really satisfy these descriptions. But sometimes we misconnect the description with experiences and sometimes we, contrariwise, do not recognize experiences as satisfying the description. In such cases we draw wrong conclusions about our sensations. It is not because we have wrong sensations; it is because we wrongly conceptualize them.

Chalmers from his side does not admit that sensations may be wrongly conceptualized. He simply demarks two kinds of properties and two kinds of conceptualization. Phenomenal properties, according to him, are fully internal, and we know them directly. It seems to me that, in fact, he supposes the existence of something like inner demonstratives too. In order to account for reflexivity Chalmers in his system introduces new notion, namely the notion of centered possible world (Chalmers 1996, 61; Chalmers 2006 , 590). It is the triplet of a possible world where a given demonstrative is used, the agent using the demonstrative, and the time when the demonstrative is used. Then he can formalize the content of a demonstrative as primary intention, which he claims to be reducible to the facts about the center with addition, probably, of some ordinary physical facts (Chalmers 1996, p. 144-145). For example, in such supplemented version of two-dimensional semantics the primary intention of "this" in my thought "This is pain" should be something like the phenomenal property of the agent's state at the present time. We can somehow generalize our experiences and form the descriptions of their phenomenal properties in mental terms. Say, I can form the belief that pain is a kind of suffering, basing on my experiences of pain and other suffering. But we cannot know directly any physical properties. Concerning every statement identifies phenomenal property with physical property we can conceive the world where this identity would not be the case. So, supposing the existence of inner demonstratives does not oblige to deny the possibility of zombie world.

Thus, Chalmers' and Perry's ways of thinking about phenomena diverge in the level, where they find the basis of the conceivability of zombies. Chalmers, the dualist, claims that it is based at the level of subject matter content. According to him, the zombie world is conceivable because phenomenal properties literally are non-physical properties. Perry, the physicalist, cannot agree with this, but he claims that at the level of reflexive content we can conceive zombies without incoherence. From his point of view, phenomenal properties seem to be other than physical properties because of their different role in thinking, especially different ways of referring to them. Chalmers' fallacy is, according to Perry, a kind of common fallacy - namely the fallacy producing by assumption that all content can be reduced to properly accounted subject matter content (Perry 2001, p. 198). The subject matter level is enough when thought content is interesting for us only with respect to its truth. But in zombie case what matters is not truth but coherence, and there are no problems with it, when we keep in mind the level of reflexive content.

Which of these two philosophers is more successful in achieving his goal? From a certain point of view, Perry is, since he has defended physicalism against Chalmers' semantic attack. From another point of view, nobody is, since Perry's arguments could not show that physicalism better explains our intuitions concerning zombies than dualism. If you have already been a dualist, you can still remain a dualist. In fact, Perry's understanding of identity theory is more than unclear. What does it mean to be identical properties which cannot be identified by concepts? How can we grasp the relations between their possible extensions? What logic would have the language suitable for the strict formulation of such statements? None of these questions have been answered in Perry's book. Because of this, even those philosophers who are generally supportive of physicalism may be dubious about his position. Nevertheless, his significant contribution to solving the zombie problem consists in the very idea of reflexive content and its explanation of what identity statements are in general. When Perry shows how this explanation works in other cases (in solving Frege's puzzle, for example), it looks very convincing. For complete success, he lacks the last step: a way to move from identity statements about objects to identity statements about properties. However, this step can be fraught with difficulties, as is often the case in the transition from first-order languages to higher orders.

\section{References}

Chalmers, D. (1996), The conscious mind. In search of a fundamental theory, Oxford University Press, Oxford, UK.

Chalmers, D. (2006), Two-Dimensional Semantics, Oxford Handbook of the Philosophy of Language, Oxford University Press, Oxford, UK.

Perry, J. (2001), Knowledge, Possibility and Consciousness, MA: MIT Press, Cambridge, UK.

Perry, J. (1993), The problem of the essential indexical and other essays, Oxford University Press, NY, Oxford.

Дата: поступления статьи: 23.07.2021

после рецензирования: 10.09.2021

принятия статьи: 30.09.2021 